\title{
The Influence of Cultural Factors on Employees' Performance at Halawanee Corporation
}

\author{
Dr. Mohammed Shehada, Dr. Sahar Abojaroor \\ Al Isra University
}

\begin{abstract}
The main objective of the study is to find out the influence of cultural factors on employee performance at Halawanee Corporation in Amman, Jordan. Oftentimes, employees work harder to achieve organizational goals if they consider themselves to be part of the corporate culture. The study asked the main question "What is the influence of cultural factorson employees' performance atHalawanee Corporation in Amman-Jordan? Hypothesis were put and tested and a model was crafted to fit the study. A questionnaire was developed and distributed to a sample of (80) employees chosen randomly from different levels and functions. Only46 out of 80 were returned and the valid ones for analysis were 38. The collected data was examined by using the SPSS (Statistical Package for Social Sciences) andthe results show that thecultural factorshas no significant influence on employee's performance atHalawanee Corporation.
\end{abstract}

Keywords: Culture, Factors, Performance, Goals, Environment, Behavior, Commitment.

\section{Introduction}

A corporate culture is defined by the practices and protocols people follow as they do their daily work. Culture also includes the values, expressed and implied, which influence the way people think and behave.

Organization is a social entity that is goal directed and purposely structured, and every organization consistsof three elements employees, goals and systems. The most important elementof those ispeople (human resources).However, as employees perform better, the organization achieves its goals in a more efficient and effective way, bearing in mind that peoplework in systems to achieve the desired output.Such process can be affected by internal and/or external surroundings or environment.Previous researchhad found employees'performance was related positively to some attributes of work environment including i.e. job satisfaction, motivation and wages(Syauta jack henry, et al 2012). In others, it was related negatively to i.e. turnover and absenteeism(Uddin Mohammad Jasimet al, 2013). Organizationalculture consists of values, behaviors, norms, beliefs, feelings, rites and rituals, written and unwritten rules in addition to other aspects. Scholars have different definitions and theories of culture but all are crafted around the same aspect.However, each organizational culture is different from others, and it seems itis difficult to make changes in the organizational culture because we live in rapidly changing times, and are likely to do so for some time to come. Therefore, it is desirable to create a culture, which is flexible and able to change rapidly when conditions require.

\section{Research Problem and its Elements:}

Most employees working at Halawanee Corporationat different levels and different functions are often not satisfied or self-motivated to perform their tasks with the highest potential they have because of the unjust treatment of employees. That led to the lowest degreeofmotivationamong employees and productionhad been dropped drastically.Therefore, the need for studying this problem is raised in order to evaluate the level of employees' performance affected or influenced by organizational culture. In order to find out a remedy for the company problems we asked the main question: (what is the influence of cultural factorson employees' performance in Halawanee Corporation?)

Then the following questions are derived from the main question:

- What is the influence of personal culture on employees' performance atHalawanee Corporation?

- What is the influence of system culture on employees' performance atHalawanee Corporation?

- What is the influence of management culture on employees' performance at Halawanee Corporation?

- Arethere differences for the effect of cultural factorson employees' performance attributedtothefunctional variable(Job title)?

- Are there differences for the effect of cultural factorson employees' performance attributedtothe (Experience)variable?

Research Hypothesis:

The main hypothesis:

- $\mathbf{H}_{0}$ : There is no statistically significant effect with a level of $(\alpha=0.05)$ for the cultural factorsonemployees' performanceatHalawanee Corporation. 
The Sub Hypotheses are:

- $\mathbf{H}_{01}$ : There is no statistically significant effect with a level of $(\alpha=0.05)$ for the personal culture onemployees' performanceatHalawanee Corporation.

- $\mathbf{H}_{02}$ : There is no statistically significant effect with a level of $(\alpha=0.05)$ for the system culture onemployees' performanceatHalawanee Corporation.

- $\mathbf{H}_{03}$ : There is no statistically significant effect with a level of $(\alpha=0.05)$ for the managementculture onemployees' performanceatHalawanee Corporation.

- $\mathbf{H}_{04}$ : There are no differences for the effect of cultural factorson employees' performance attributed to the functional variable such as (Job title) atHalawanee Corporation.

- $\mathbf{H}_{05}$ : There are no differences for the effect of cultural factorson employees' performance attributed to the (Experience) variableatHalawanee Corporation.

\section{Research Model}

Independent VariablesDependent Variables

(CulturalFactors) (Employees' Performance)

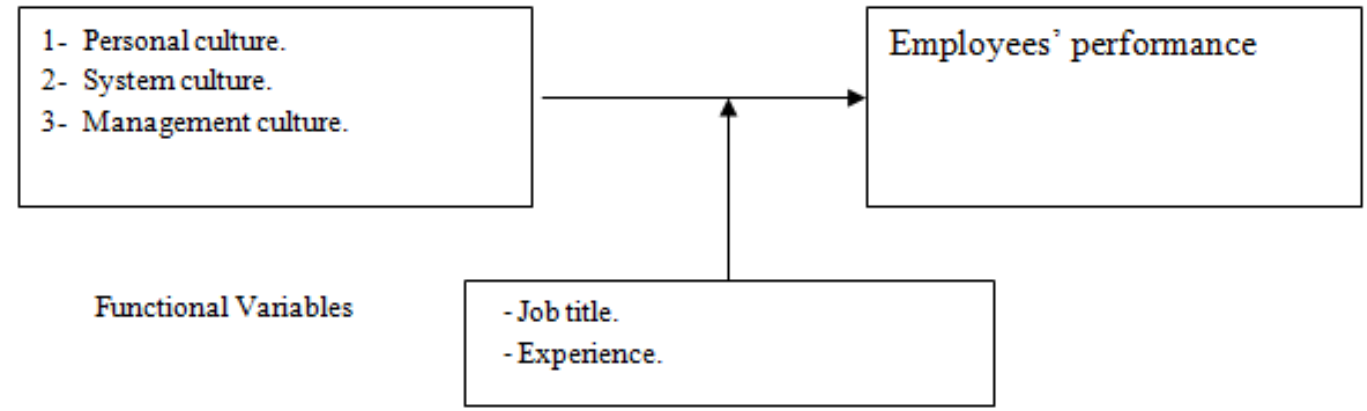

Sources: Allaire\&Firsirotu, M. E., Theories of organizational culture(1984), Al-Sarayreh, M.,The relation between organizational culture and creativity(2003).

\section{Procedural Definitions:}

Organizational Culture: Schein (1990) definescultural factors as the common values and behaviors ofpeople that areconsidered as a tool which leads to the successful achievement of organizational goals. WhileHofstede (1991) emphasized that organizational culture is the mindset of people that distinguishesthem from each other, within the organization or outside theorganization. This includes values,beliefs, and behaviors of employeesversus the other organization. Organizationalculture means stable arrangements of beliefs and norms, which are held commonly by a societyor department in the organization (Kotter and Heskett, 1992).Strong culture in the organization is very helpful to enhance the performance of theemployees that leads to the goal achievement and increases the overall performance of theorganization (Deal and Kennedy, 1982). Employee's performance means the ability ofemployees to attain goals either personal or organizational by using resources efficiently andeffectively (Daft, 2010).

We strongly believe that organizational culture is a combination of beliefs, attitudes, norms, needs,behaviors, andritesand rituals that determine and control the relationship ofemployees among each other and theirrelation with the organization they work for. Therefore, it affects the way employees performing their job. Currently,in the time of change, it is considered a big challenge for any organization to change its culture because of rapid environmental variation.

PersonalCulture: Personal culture is the culture in which the corporate performs its tasks for the benefits of its members ignoring the official organization structure and policies.In addition to that, the process of controlling and managing the organization is a mutual agreed process.

System Culture:System culture is the culture in which the corporate performing its tasks according to the applied systems and policies.Here the job tasks are designed to fit special skills and requirements as well as the direction. The commands flow from the top to the bottom of the organization structure.Besides, the decisions are made according to the authority matrix.

Management Culture: Management culture is the culture in which the corporate performing its tasks according to the management style and conceptual thinking. Either the management can be open-minded, innovative, supportive, motivated, encourage mutual decisions,just, flexible and accept other opinions and suggestions or be close-minded, refuse change, unfair, and don't accept other opinions or suggestions.

Employees'Performance: Employees' performance is the degree to which the organization achievesits planned or expected results thru its members. However, the appraisal system used in the company under research include the quality and quantity of work done, time keeping and attendance, lessons learned (no repetition for the same complaint or mistake), communication, attitude towards job, problem solving, job knowledge and safety habits. 
Importance of the Study: This research has a high degree of importanceas it will reveal the relationship between the cultural factors and employee's performance, and it will solve the problems associated with this study if a significant influence is evident.

Population of the Study: The population of the study is the employees of Halawanee Corporation- one of the Halawanee Corporationmembers- located in Amman-Jordan. The total number of employees working at Halawanee Corporation is (226) working in two shifts which cover 24 hours a day 7 days a week.

Sample of the Study: The sample of this study included (80) employees chosen randomly among all employees within different shifts from different levels and functions.

Sampling Unit: With the help of human resources department atHalawanee Corporation,the distributed questionnaires were returned after two days.The returned filled questionnaires were 46 out of 80 and the valid ones that were good for analysis were 38 .

Sources ofInformation: The information gathered in this paperis categorized mainlyas secondary sources and primary ones. The secondary informationwas gathered from journals, books, thesis and dissertations, magazines, and search engines.Primary sourcesweregathered from distributing aquestionnaire that was designed and articulated by a group of specialists in the field of culture to answer the paragraphs of the questionnaire.

Validity of Tools Measurements: In the context of this subject Cronbach's Alpha is used as an index of reliability.Cronbach's alpha determines the internal consistency or average correlation of items in the questionnaire to gauge its reliability, as it considered very important to know whether the same set of items would elicit the same responses if the same questions are recast and re-administered to the same respondents. Measures derived from questionnaire are declared to be reliable only when they provide stable and reliable responses over a repeated administration of the questionnaire (Cronbach's Alpha factor should be $>70 \%$ to get valid and reliable results).

\section{Limitations of the Study:}

The study was limited to a small corporation located in Amman/Jordan and normally employees working at small companies have strong cultural ties than huge corporations. Halawanee Corporation, however, is a family business and any information about this company is considered a top secret to the owners. We were able to distribute our questionnaire only through a person working at the human resources department. Therefore, checking the reliability and validity of this study would be hard to make.

\section{Statistical Analysis:}

The collected data was examined by using the SPSS (Statistical Package for Social Sciences) andthe results show that the organizational culture has no significant influence on employee's performance at Halawanee Corporation. Descriptive statistics and frequencies were used to figure out the measures of central tendency (average or mean, median and mode)in addition to standard deviation. Table (1) shows the distribution of sample study according to the functional variable (job title)

Table (1)

\begin{tabular}{|l|l|l|l|l|}
\hline Job title & Frequency & Percent & Cumulative Percent \\
\hline Valid & Manager & 3 & 7.9 & 7.9 \\
\cline { 2 - 5 } & Section head & 6 & 15.8 & 23.7 \\
\cline { 2 - 5 } & Engineer & 3 & 7.9 & 31.6 \\
\cline { 2 - 5 } & Officer & 7 & 18.4 & 50.0 \\
\cline { 2 - 5 } & Supervisor & 1 & 2.6 & 52.6 \\
\cline { 2 - 5 } & Inspector & 3 & 7.9 & 60.5 \\
\cline { 2 - 5 } & Technician & 6 & 15.8 & 76.3 \\
\cline { 2 - 5 } & Laborer & 6 & 15.8 & 92.1 \\
\cline { 2 - 5 } & Other & 3 & 7.9 & 100.0 \\
\cline { 2 - 5 } & Total & 38 & 100.0 & \\
\hline
\end{tabular}

From the given table, we can conclude that the highest percent of employees are officers then section heads, then technicians and laborers and then others.

Table (2) shows the distribution of sample study according to functional variable (experience).

Table (2)

\begin{tabular}{|l|l|l|l|l|}
\hline Experience & Frequency & Percent & Cumulative Percent \\
\hline Valid & Less than 5 Years & 14 & 36.8 & 36.8 \\
\cline { 2 - 5 } & 5 to less than 10 years & 13 & 34.2 & 71.1 \\
\cline { 2 - 5 } & 10 to less than 15 years & 2 & 5.3 & 76.3 \\
\cline { 2 - 5 } & 15 years and more & 9 & 23.7 & 100.0 \\
\cline { 2 - 5 } & Total & 38 & 100.0 & \\
\hline
\end{tabular}


The table above indicates that the experience of employeesis $36.8 \%$ for less than five years followed by $34.2 \%$ for five to less than ten years,5.3\% for ten to less than fifteen yearsand finally $23.7 \%$ for fifteen years and above. Table (3) shows the distribution of Likert Scale for the statements of personal culture

Table (3)

\begin{tabular}{|c|c|c|c|c|c|c|c|c|c|}
\hline Personal Culture & $\frac{\mathscr{D}}{\tilde{\sigma}}$ & 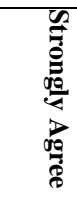 & $\frac{8}{80}$ & 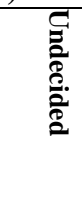 & 焉. & 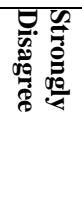 & है. & $\stackrel{\infty}{\because}$ & 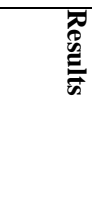 \\
\hline \multirow{2}{*}{$\begin{array}{l}\text { 1.The company performs its duties } \\
\text { for its benefit and the benefit of its } \\
\text { employees }\end{array}$} & Freq. & 8 & 19 & 5 & 3 & 3 & \multirow[t]{2}{*}{3.68} & \multirow[t]{2}{*}{1.141} & \multirow[t]{2}{*}{ Agree } \\
\hline & $\%$ & 21.1 & 50 & 13.2 & 7.9 & 7.9 & & & \\
\hline \multirow{2}{*}{$\begin{array}{l}\text { 2.The company controls its work } \\
\text { and that is done by mutual } \\
\text { agreement with its employees }\end{array}$} & Freq. & 4 & 26 & 6 & 2 & 0 & \multirow[t]{2}{*}{3.84} & \multirow[t]{2}{*}{.679} & \multirow[t]{2}{*}{ Agree } \\
\hline & $\%$ & 10.5 & 68.4 & 15.8 & 5.3 & 0 & & & \\
\hline \multirow{2}{*}{$\begin{array}{l}\text { 3. The Company's management } \\
\text { method is based on mutual } \\
\text { agreement between its members }\end{array}$} & Freq. & 3 & 17 & 5 & 8 & 5 & \multirow[t]{2}{*}{3.13} & \multirow[t]{2}{*}{1.234} & \multirow{2}{*}{$\begin{array}{l}\text { undeci } \\
\text { ded }\end{array}$} \\
\hline & $\%$ & 7.9 & 44.7 & 13.2 & 21.1 & 13.2 & & & \\
\hline \multirow{2}{*}{$\begin{array}{l}\text { 4. I do my work independently } \\
\text { andfar from pressure }\end{array}$} & Freq. & 10 & 18 & 2 & 5 & 3 & \multirow[t]{2}{*}{3.71} & \multirow[t]{2}{*}{1.228} & \multirow[t]{2}{*}{ Agree } \\
\hline & $\%$ & 26.3 & 47.4 & 5.3 & 13.2 & 7.9 & & & \\
\hline \multirow{2}{*}{$\begin{array}{l}\text { 5. There are good relations } \\
\text { between staff and managers }\end{array}$} & Freq. & 11 & 21 & 3 & 2 & 1 & \multirow[t]{2}{*}{4.03} & \multirow[t]{2}{*}{.915} & \multirow[t]{2}{*}{ Agree } \\
\hline & $\%$ & 28.9 & 55.3 & 7.9 & 5.3 & 2.6 & & & \\
\hline \multirow[b]{2}{*}{ Results of personal culture } & Freq. & 36 & 101 & 21 & 20 & 12 & \multirow[t]{2}{*}{3.64} & \multirow[t]{2}{*}{.721} & \multirow[t]{2}{*}{ Agree } \\
\hline & $\%$ & 18.94 & 53.16 & 11.08 & 10.56 & 6.32 & & & \\
\hline
\end{tabular}

It can be seen from the table above that the results of personal culture is (3.64) which means (agree) based on the samples of the study analyzed, as the variables which represent our options are (strongly agree, agree, undecided, disagree and strongly disagree) and such being reflected on numbers on SPSS program as positively means $(5=$ strongly agree, $4=$ agree, $3=$ undecided, $2=$ disagree, $1=$ strongly disagree). For this it was considered 0.8 as an interval distance resulted from ( 4 divided by 5 ). Therefore, the following categories are considered:

From $1.0-1.79$ : strongly disagree.

From $1.80-2.59$ : disagree.

From 2.60 - 3.39: undecided.

From 3.40- 4.19: agree.

From 4.2- 5.0: strongly agree.

Table (4) shows the descriptive statistics for system culture

\begin{tabular}{|c|c|c|c|c|c|c|c|c|c|}
\hline \multicolumn{10}{|c|}{ Table (4) } \\
\hline System Culture & $\frac{\mathscr{C}}{\tilde{\sigma}}$ & 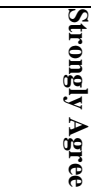 & $\frac{8}{8}$ & 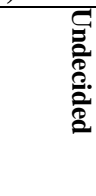 & : & 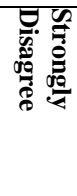 & 胥. & $\stackrel{\mathscr{Q}}{?}$ & 悉 \\
\hline \multirow{2}{*}{$\begin{array}{l}\text { 6. The company complies with its } \\
\text { policies, procedures and regulations }\end{array}$} & Freq. & 11 & 9 & 7 & 0 & 1 & \multirow[t]{2}{*}{4.03} & \multirow[t]{2}{*}{.854} & \multirow[t]{2}{*}{ Agree } \\
\hline & $\%$ & 28.9 & 50 & 18.4 & 0 & 2.6 & & & \\
\hline \multirow{2}{*}{$\begin{array}{l}7 . \quad \text { The responsibility and } \\
\text { distribution of work is done } \\
\text { according to the employee's skills. }\end{array}$} & Freq. & 7 & 17 & 5 & 7 & 2 & \multirow[t]{2}{*}{3.53} & \multirow{2}{*}{$\begin{array}{l}1.15 \\
6\end{array}$} & \multirow[t]{2}{*}{ Agree } \\
\hline & $\%$ & 18.4 & 44.7 & 13.2 & 18.4 & 5.3 & & & \\
\hline \multirow{2}{*}{$\begin{array}{l}\text { 8. The selection and hiring of staffis } \\
\text { based on job requirements needed. }\end{array}$} & Freq. & 6 & 16 & 9 & 4 & 3 & \multirow[t]{2}{*}{3.47} & \multirow{2}{*}{$\begin{array}{l}1.13 \\
3\end{array}$} & \multirow[t]{2}{*}{ Agree } \\
\hline & $\%$ & 15.8 & 42.1 & 23.7 & 10.5 & 7.9 & & & \\
\hline \multirow{2}{*}{$\begin{array}{l}\text { 9. Communications in the company } \\
\text { flow from top to bottom }\end{array}$} & Freq. & 5 & 27 & 5 & 1 & 0 & \multirow[t]{2}{*}{3.95} & \multirow[t]{2}{*}{.613} & \multirow[t]{2}{*}{ Agree } \\
\hline & $\%$ & 13.2 & 71.1 & 13.2 & 2.6 & 0 & & & \\
\hline \multirow{2}{*}{$\begin{array}{l}10 . \text { Staff communication is } \\
\text { according to the organizational } \\
\text { structure. }\end{array}$} & Freq. & 7 & 27 & 2 & 2 & 0 & \multirow[t]{2}{*}{4.03} & \multirow[t]{2}{*}{.677} & \multirow[t]{2}{*}{ Agree } \\
\hline & $\%$ & 18.4 & 71.1 & 5.3 & 5.3 & 0 & & & \\
\hline \multirow{2}{*}{$\begin{array}{l}\text { 11. Decisions and approvals are } \\
\text { being made according to the } \\
\text { approved authority matrix. }\end{array}$} & Freq. & 12 & 22 & 3 & 1 & 0 & \multirow[t]{2}{*}{4.18} & \multirow[t]{2}{*}{.692} & \multirow[t]{2}{*}{ Agree } \\
\hline & $\%$ & 31.6 & 57.9 & 7.9 & 2.6 & 0 & & & \\
\hline \multirow[t]{2}{*}{ Total } & Freq. & 48 & 110 & 31 & 15 & 6 & \multirow[t]{2}{*}{3.87} & \multirow[t]{2}{*}{.628} & \multirow[t]{2}{*}{ Agree } \\
\hline & $\%$ & 21.05 & 56.15 & 13.62 & 6.57 & 2.63 & & & \\
\hline
\end{tabular}

The table above shows that the system culture as independent variable has a total median of 3.87.

Table (5) shows the descriptive statistics for management culture as independent variable

Table (5) 


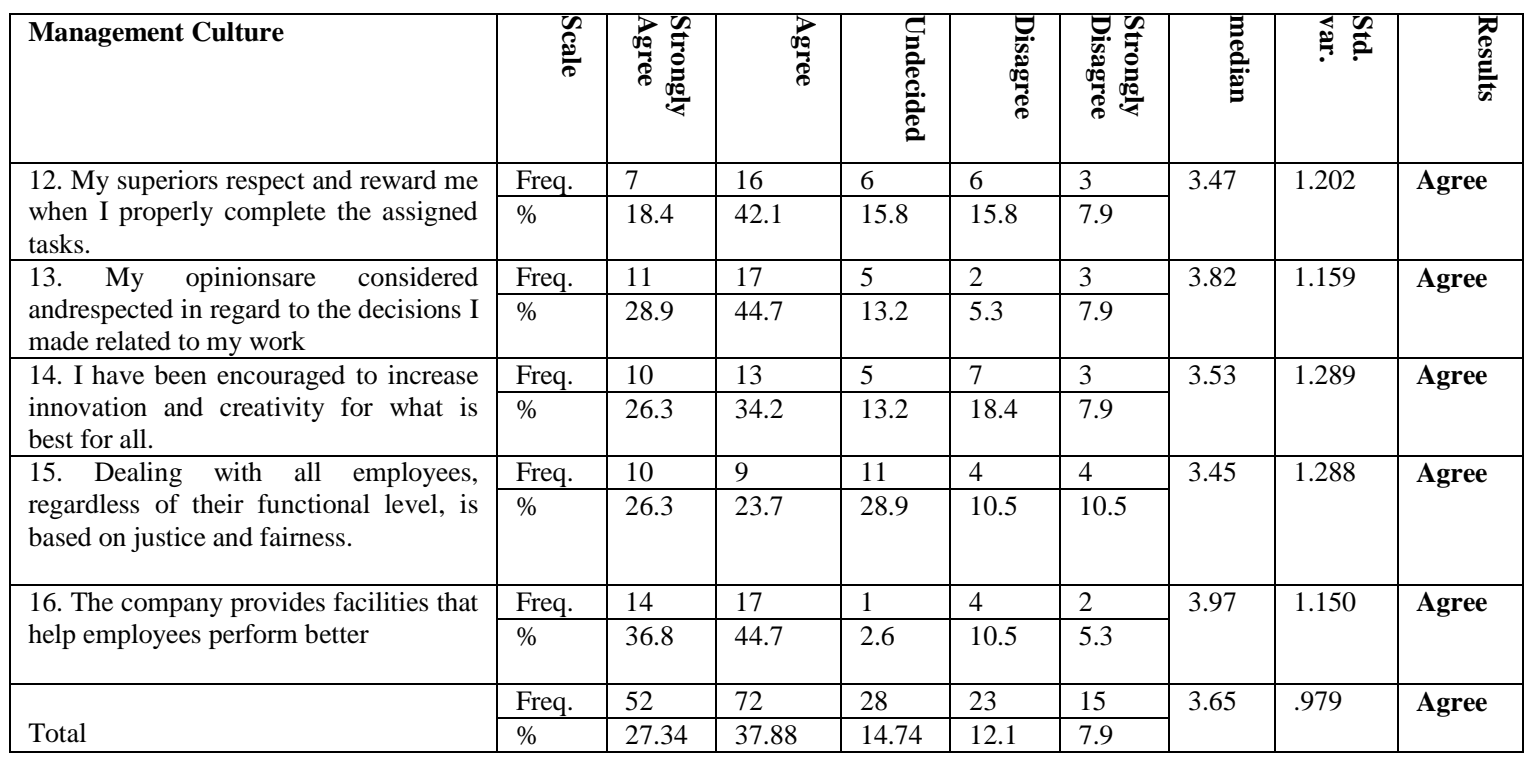

The table above shows a median of 3.65 (agree) for the management culture as independent variable Table (6) shows the descriptive statistics for employee's performance as dependent variables

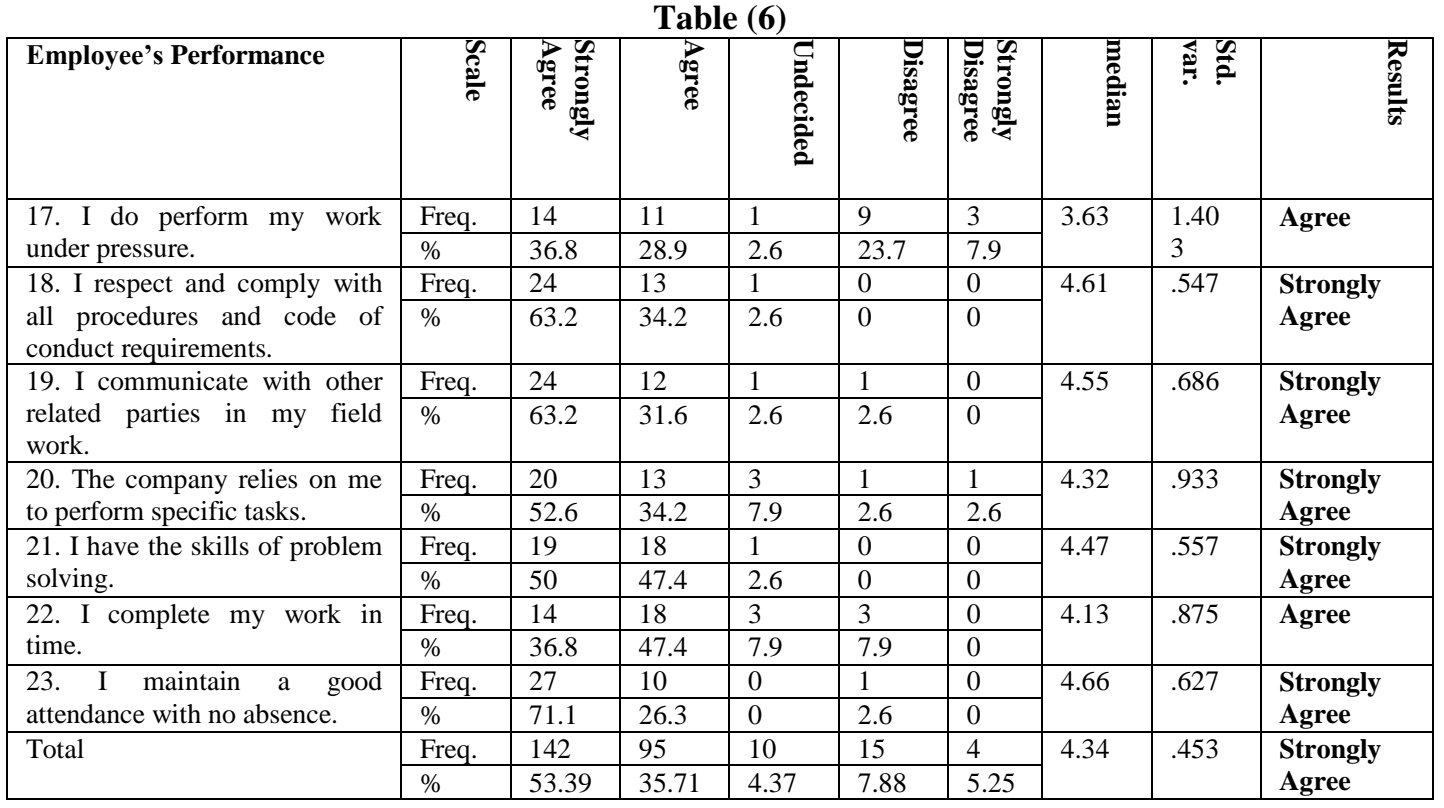

The table above shows a median of 4.34 (strongly agree) for the employee's performance as dependent variable. It is noticed from the previous tables that all types of organizational culture (personal, system and management) which act as independent variables are implemented in the organization.Also, the dependent variable (employee's performance) is also implemented in Halawanee Corporation.

Inferential Statistics:

The hypotheses were being tested using linear regression test.

Table (7) shows thelinear correlation between the dependent and the independent variables

Table (7)

\begin{tabular}{|l|l|l|l|l|}
\hline \multicolumn{4}{|l|}{ Model Summary } \\
\hline Model & $\mathrm{R}$ & $\mathrm{R}$ Square & Adjusted R Square & Std. Error of the Estimate \\
\hline 1 & $.280^{\mathrm{a}}$ & .078 & -.003 & .45416 \\
\hline \multicolumn{2}{|l|}{ a. Predictors: (Constant), Management culture, System culture, Personal culture } \\
\hline
\end{tabular}

The value of $\mathrm{R}$ is 0.28 and this is considered a low value to make a strong relation between these variables. 
Table (8): Analysis of variables for regression line.

The Hypothesis was being tested using linear regression test as shown below:

Table (8)

\begin{tabular}{|c|c|c|c|c|c|c|}
\hline \multicolumn{7}{|c|}{ ANOVA $^{b}$} \\
\hline & del & Sum of Squares & $\mathrm{df}$ & Mean Square & $\mathrm{F}$ & Sig. \\
\hline \multirow[t]{3}{*}{1} & Regression & .596 & 3 & .199 & .963 & $.421^{\mathrm{a}}$ \\
\hline & Residual & 7.013 & 34 & .206 & & \\
\hline & Total & 7.609 & 37 & & & \\
\hline
\end{tabular}

a. Predictors: (Constant), Management culture, System culture, Personal culture

b. Dependent Variable: Employee's performance

As the value of Sig is $0.421>0.05$, therefore we accept the hypothesis made for this analysis of (the line of regression does not fit with given data).

Table (9): Multiple Regression analysis to test the influence of variables on the dependent variable.

Table (9)

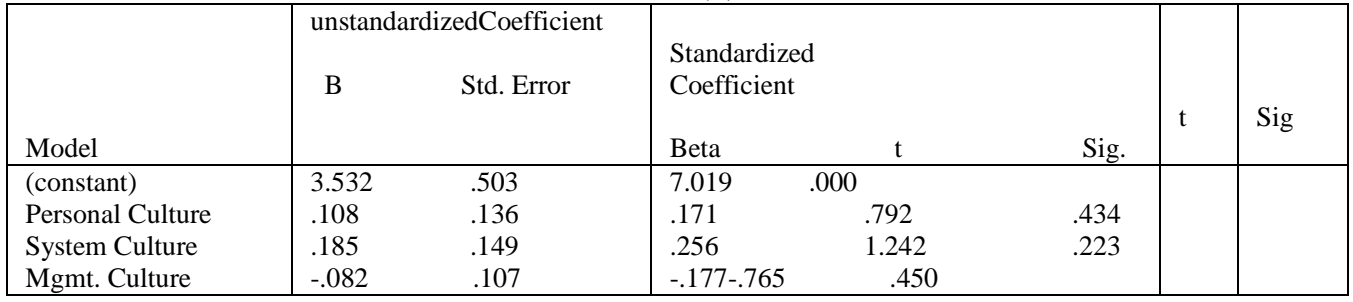

Coefficients ${ }^{\text {a }}$

a.Dependent variable: Employee performance

It can be seen from the given table (9) that the level of significant of (t) value for all independent variables (personal, system and management culture) are $0.434,0.233$ and 0.450 respectively, these values are higher than 0.05 , therefore we accept the null hypotheses made at the beginning of this paper:

- $\quad \mathbf{H}_{01}$ : There is no statistically significant effect with a level of $(\alpha=0.05)$ for the personal culture onemployees' performanceatHalawanee Corporation.

- $\quad \mathbf{H}_{\mathbf{0 2}}$ : There is no statistically significant effect with a level of $(\alpha=0.05)$ for the system culture onemployees' performanceatHalawanee Corporation.

- $\quad \mathbf{H}_{\mathbf{0 3}}$ : There is no statistically significant effect with a level of $(\alpha=0.05)$ for the managementculture onemployees' performanceatHalawanee Corporation.

Table (10) shows the descriptive statistic for the dependent and independent variables according to the variable (experience).

Table (10)

\begin{tabular}{|c|c|c|c|c|c|c|c|c|c|}
\hline \multicolumn{10}{|c|}{ Descriptive } \\
\hline & \multirow[t]{2}{*}{$\mathrm{N}$} & \multirow[t]{2}{*}{ Mean } & \multirow[t]{2}{*}{$\begin{array}{l}\text { Std. } \\
\text { Deviation }\end{array}$} & \multirow[t]{2}{*}{$\begin{array}{l}\text { Std. } \\
\text { Error }\end{array}$} & \multicolumn{2}{|c|}{$\begin{array}{l}95 \% \text { Confidence } \\
\text { Interval for Mean }\end{array}$} & \multirow[t]{2}{*}{$\begin{array}{l}\text { Minimu } \\
\mathrm{m}\end{array}$} & \multirow[t]{2}{*}{$\begin{array}{l}\text { Maximu } \\
\mathrm{m}\end{array}$} \\
\hline & & & & & & $\begin{array}{l}\text { Lower } \\
\text { Bound }\end{array}$ & $\begin{array}{l}\text { Upper } \\
\text { Bound }\end{array}$ & & \\
\hline \multirow{5}{*}{ 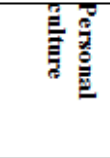 } & Less Than 5 Years & 14 & 3.3714 & .88355 & .23614 & 2.8613 & 3.8816 & 2.20 & 5.00 \\
\hline & 5 to less than 10 years & 13 & 3.8308 & .42305 & .11733 & 3.5751 & 4.0864 & 3.20 & 4.60 \\
\hline & 10 to less than 15 years & 2 & 2.9000 & .42426 & .30000 & -.9119 & 6.7119 & 2.60 & 3.20 \\
\hline & 15 years and more & 9 & 3.9333 & .65574 & .21858 & 3.4293 & 4.4374 & 3.00 & 5.00 \\
\hline & Total & 38 & 3.6368 & .72164 & .11707 & 3.3996 & 3.8740 & 2.20 & 5.00 \\
\hline \multirow{5}{*}{ 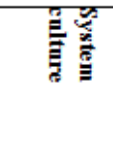 } & Less Than 5 Years & 14 & 3.7738 & .73265 & .19581 & 3.3508 & 4.1968 & 2.67 & 5.00 \\
\hline & 5 to less than 10 years & 13 & 3.8333 & .62361 & .17296 & 3.4565 & 4.2102 & 3.00 & 5.00 \\
\hline & 10 to less than 15 years & 2 & 3.5833 & .35355 & .25000 & .4068 & 6.7599 & 3.33 & 3.83 \\
\hline & 15 years and more & 9 & 4.1296 & .49144 & .16381 & 3.7519 & 4.5074 & 3.17 & 4.83 \\
\hline & Total & 38 & 3.8684 & .62860 & .10197 & 3.6618 & 4.0750 & 2.67 & 5.00 \\
\hline \multirow{5}{*}{ 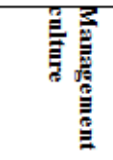 } & Less Than 5 Years & 14 & 3.1143 & .96305 & .25739 & 2.5582 & 3.6703 & 2.00 & 5.00 \\
\hline & 5 to less than 10 years & 13 & 3.9231 & 92209 & .25574 & 3.3659 & 4.4803 & 1.60 & 5.00 \\
\hline & 10 to less than 15 years & 2 & 2.9000 & .70711 & .50000 & -3.4531 & 9.2531 & 2.40 & 3.40 \\
\hline & 15 years and more & 9 & 4.2444 & .65405 & .21802 & 3.7417 & 4.7472 & 3.00 & 5.00 \\
\hline & Total & 38 & 3.6474 & 97917 & .15884 & 3.3255 & 3.9692 & 1.60 & 5.00 \\
\hline \multirow{5}{*}{ 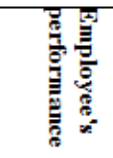 } & Less Than 5 Years & 14 & 4.3265 & .20533 & .05488 & 4.2080 & 4.4451 & 3.86 & 4.71 \\
\hline & 5 to less than 10 years & 13 & 4.2088 & .57326 & .15899 & 3.8624 & 4.5552 & 3.43 & 5.00 \\
\hline & 10 to less than 15 years & 2 & 4.5000 & .70711 & .50000 & -1.8531 & 10.8531 & 4.00 & 5.00 \\
\hline & 15 years and more & 9 & 4.5079 & .51066 & .17022 & 4.1154 & 4.9005 & 3.43 & 5.00 \\
\hline & Total & 38 & 4.3383 & .45349 & .07357 & 4.1893 & 4.4874 & 3.43 & 5.00 \\
\hline
\end{tabular}


In table (11) ANOVA is used to test the differences of the effect of organizational culture on employees' performance attributedto thevariable (Experience)

Table (11)

\begin{tabular}{|c|c|c|c|c|c|c|}
\hline \multicolumn{7}{|c|}{ ANOVA } \\
\hline & & Sum of Squares & $\mathrm{df}$ & Mean Square & $\mathrm{F}$ & Sig. \\
\hline \multirow{3}{*}{ Personal culture } & Between Groups & 3.352 & 3 & 1.117 & 2.387 & .086 \\
\hline & Within Groups & 15.916 & 34 & .468 & & \\
\hline & Total & 19.268 & 37 & & & \\
\hline \multirow[t]{3}{*}{ System culture } & Between Groups & .918 & 3 & .306 & .759 & .525 \\
\hline & Within Groups & 13.702 & 34 & .403 & & \\
\hline & Total & 14.620 & 37 & & & \\
\hline \multirow[t]{3}{*}{ Management culture } & Between Groups & 9.292 & 3 & 3.097 & 4.022 & .015 \\
\hline & Within Groups & 26.182 & 34 & .770 & & \\
\hline & Total & 35.475 & 37 & & & \\
\hline \multirow[t]{3}{*}{ Employee's performance } & Between Groups & .531 & 3 & .177 & .851 & .476 \\
\hline & Within Groups & 7.078 & 34 & .208 & & \\
\hline & Total & 7.609 & 37 & & & \\
\hline
\end{tabular}

Table (11) shows the value of F Sig.and it is higher than 0.05 for all variables except for management culture (0.015), therefore we reject the null hypothesis.

$\mathbf{H}_{05}$ : There are no differences for the effect of organizational culture on employees' performance attributedtothe variable (Experience).

Accordingly, we accept the alternative hypothesis:There are differences for the effect of organizational culture on employees' performance attributedtovariable (Experience).

Table (12): Descriptive statistics for the dependent and independent variables according to the variable (Job title).

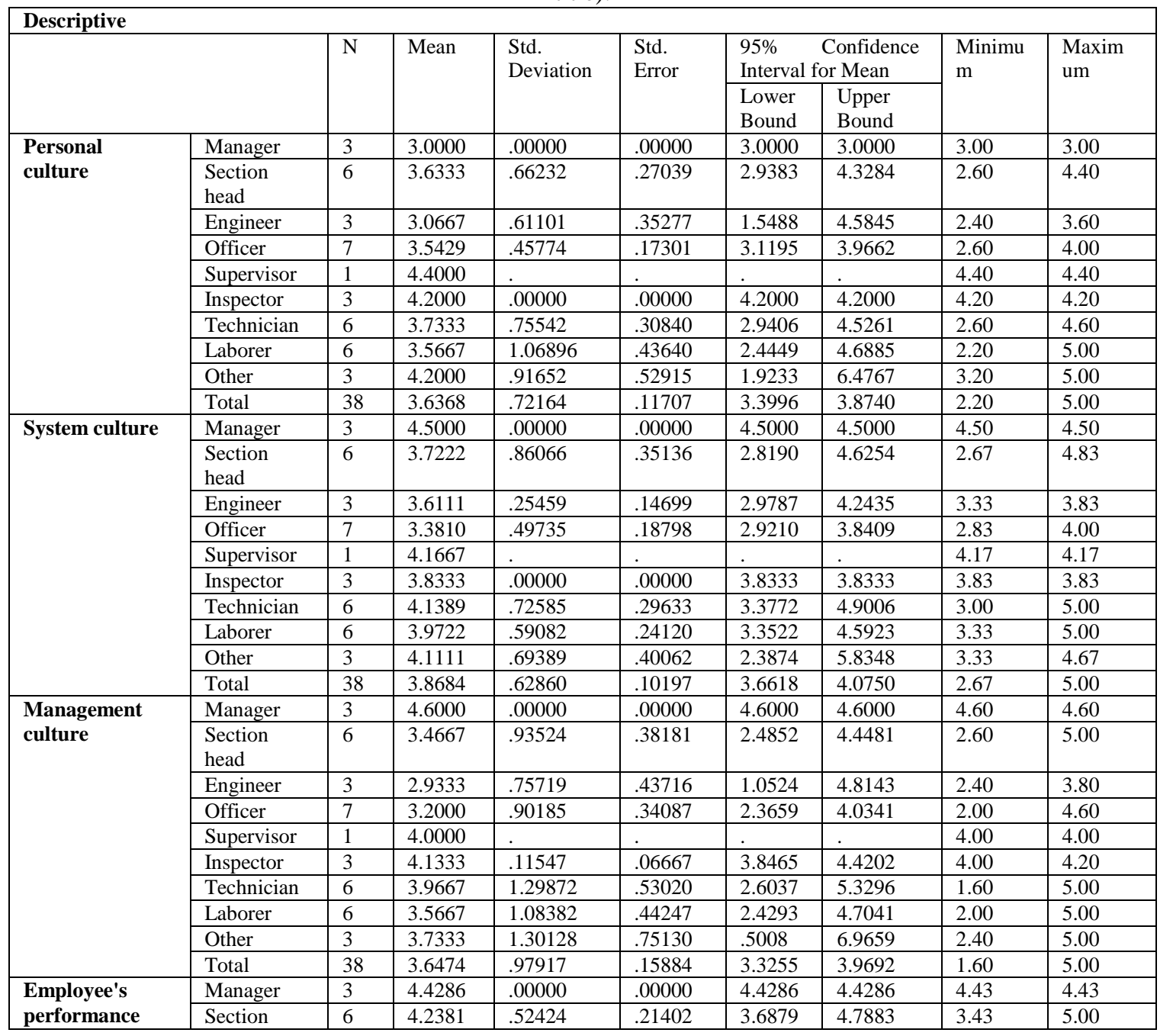


The Influence of Cultural Factors on Employees' Performance at Halawanee Corporation

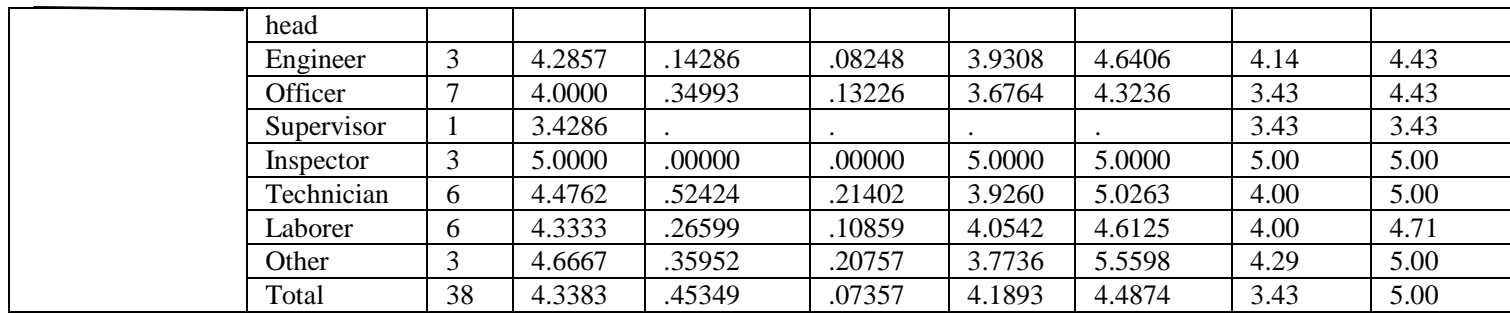

The above table shows the descriptive statistic for each variable categorized for job title as the demographic variable (mean, standard deviation, Std. error, interval for confidence, minimum and maximum values).

Table (13): One way ANOVA to test the differences of the effect of organizational culture on employees' performance attributedto the demographic variable (Job title).

Table (13)

\begin{tabular}{|c|c|c|c|c|c|c|}
\hline \multicolumn{7}{|l|}{ ANOVA } \\
\hline & & $\begin{array}{l}\text { Sum of } \\
\text { Squares }\end{array}$ & $\mathrm{df}$ & $\begin{array}{l}\text { Mean } \\
\text { Square }\end{array}$ & $\mathrm{F}$ & Sig. \\
\hline \multirow[t]{3}{*}{ Personal culture } & Between Groups & 4.825 & 8 & .603 & 1.211 & .327 \\
\hline & Within Groups & 14.444 & 29 & .498 & & \\
\hline & Total & 19.268 & 37 & & & \\
\hline \multirow[t]{3}{*}{ System culture } & Between Groups & 3.960 & 8 & .495 & 1.347 & .261 \\
\hline & Within Groups & 10.660 & 29 & .368 & & \\
\hline & Total & 14.620 & 37 & & & \\
\hline \multirow[t]{3}{*}{ Management culture } & Between Groups & 7.355 & 8 & .919 & .948 & .494 \\
\hline & Within Groups & 28.120 & 29 & .970 & & \\
\hline & Total & 35.475 & 37 & & & \\
\hline \multirow{3}{*}{$\begin{array}{l}\text { Employee's } \\
\text { performance }\end{array}$} & Between Groups & 3.473 & 8 & .434 & 3.044 & .013 \\
\hline & Within Groups & 4.136 & 29 & .143 & & \\
\hline & Total & 7.609 & 37 & & & \\
\hline
\end{tabular}

From theabovetable, we can see that the value of F Sig. is higher than 0.05 for all variables except for employee's performance (0.013), therefore we reject the null hypothesis:

$\mathbf{H}_{04}$ : There are no differences for the effect of organizational culture on employees' performance attributed tothe demographic variable (Job title).And accordingly,we accept the alternative hypothesis:There are differences for the effect of organizational culture on employees' performance attributedtothe variable (Job title).

\section{Results \&Conclusions}

When discussing how to change a corporate culture, it is useful to consider several related issues. Firstly,gaining acceptance of the need to change; Secondly,defining the nature of the change and what will be different; and thirdly defining what must be learned. Based on the statistical analysis presented above, this paper demonstrated that the three attributes of organizational culture (personal, system and management cultures) have no statistical significant influence with a level of $(\alpha=0.05)$ over the employee's performance at Halawanee Corporation.Therefore, we accept the null hypothesis for the main question of this study and also accept the other three hypotheses of the organizational culture aspects. Although it was found that there are differences of the effect of cultural factors on employees' performance attributedto demographical variables (Job title and experience). Therefore, we reject the null hypotheses and accept the alternative hypotheses in regard to the demographic variables.

1- There is no statistically significant effect with a level of $(\alpha=0.05)$ for the cultural factorsonemployees' performanceatHalawanee Corporation.

2- There is no statistically significant effect with a level of $(\alpha=0.05)$ for the personal culture onemployees' performanceatHalawanee Corporation.

3- There is no statistically significant effect with a level of $(\alpha=0.05)$ for the system culture onemployees' performanceatHalawanee Corporation.

4- There is no statistically significant effect with a level of $(\alpha=0.05)$ for the managementculture onemployees' performanceatHalawanee Corporation.

5- There are differences for the effect of cultural factorson employees' performance attributedto thefunctional variable (Job title).

6- There are differences for the effect of cultural factorson employees' performance attributedtothefunctional variable (Experience). 
This paper has found that the three aspects of organizational culture (personal, system and management cultures)are widely used in Halawanee Corporation, and theaverage mean of 3.72 according to Likert scale means (agree). Also it was found that the performance of employees was high with 4.34 mean value and according to Likert scale means (strongly agree).

\section{Recommendations}

A Change of Culture must be "led", it cannot be just "managed '. The changing of a corporate culture occurs through education. People are required to learn new skills and, to an even larger degree, abandon old ways of thinking.The most difficult part of changing the way people behave is not so much a matter of teaching them something new; it is mostly a matter of teaching them to forget things, which are either incorrect or no longer applicable.Adaptingto an open system, associated with high cultural values, play a vital role in improving the performance of employees and the organization as a whole. By inspiring the innovative environment and encourage people to share their thoughts and ideas will help the corporation to adopt to the rapid pace of environment change and the uncertainty characterized by today's environment.

The top management of any organization is the main key to achieve successful culture. They aretheoneswholead the whole organization toward achieving the set goals thru different means and behaviors. that are linked to the cultural values adopted by the company which in turn will be reflected on all employees as they influenced and guided by the top management which finally lead to sustainable long-termsuccess of the organization. For the organizational culture change to be successful the following can be adopted:

- making learning part of working so the enterprise may continue without paying too high a price for the educational activities

- educating entire hierarchy so that practices and procedures of enterprise reinforce what is taught and people help one another learn

- defining knowledge, skills, and competencies which must be learned.

\section{References}

[1]. Ali Mohammad Safania, SeyyedJafarMoosavi, SeyyedAbolfazle Tajali1 (2013), "The relationship between Organizational Culture and creativity in Physical Education Experts in University of Applied Science and Technology" International Journal of Sport Studies. Vol., 3 (11), 1237-1245.

[2]. Allaire\&Firsirotu, M. E. (1984) Theories of organizational culture. Searching engine (Google: 17th Nov. /2014).

[3]. Aluko, M. A. O., (2003), "The Impact of Culture on Organizational Performance", Nordic Journal of African Studies, 12(2): PP: $164-179$.

[4]. Alvi Huma Abidet al, (2014) "Impact of Organizational Culture on Organizational Commitment and Job Satisfaction" European Journal of Business and Management. Vol. 6, No. 27, PP 35-42

[5]. Daft, R. L. (2010). New Era of management, South Western Book, Australia.

[6]. Hofstede (1991), Cultures and Organizations. Searching engine (Google: 17th Nov. /2014).

[7]. Julia C. Naranjo-Valencia, Daniel Jiménez-Jiménez, Raquel Sanz-Valle, (2016) "Studying the Links Between Organizational Culture, Innovation, and Performance in Spanish Companies", RevistaLatinoamericanaPsicologia, Vol. 48. Núm. 1.

[8]. Kotter and Heskett (1992), corporate culture and performance. Searching engine (Google: 17th Nov. /2014).

[9]. Mir AbdolhasanAskariRankouh, PayamNikbakhshSaberi Poor, ( 2013 ), "Examine the Relationship between Organizational Culture and Creativity of Lecturers", Universal Journal of Management and Social Sciences,Vol. 3, No.8; 24-30

[10]. Negar Saleh Mobarakah, (2011), Social and Behavioral Sciences, Volume 15, Pages 1-4106,3rd World Conference on Educational Sciences - 2011 Istanbul, Turkey

[11]. Ojo, Olu (2009), "Impact Assessment of Corporate Culture on Employee Job Performance", Business Intelligence Journal, PP (388-397). Searching engine (Google: 9th Dec. /2014).

[12]. OsibanjoOmotayoAdewale, AdenijiAdenikeAnthonia, (2013), "Impact of Organizational Culture on Human Resource Practices: A Study of Selected Nigerian Private Universities", Journal of Competitiveness, Vol. 5, Issue 4, pp. 115-133

[13]. Pieterse, Anne Nederveen et al, (2013) "Cultural Diversity and Team Performance: The Role of Team Member Goal Orientation" Academy of Management Journal, Vol. 56, No. 3, PP (782-804)

[14]. Salimi, Hojjat Ali, Aveh, Mahbobeh Chin, (2016) "Job enrichment Corporate culture Innovations", Indian Journal of Positive Psychology,VOLUME/ISSUE: Vol. 7, No. 1, PP 34

[15]. Seyyedgafarmoosavi , Zynabyousfi, (2013), “The relationship between organizational culture, Organizational Commitment and creativity of Physical Education Secretaries in Mazandaran Province mortezadousti” , International Research Journal of Applied and Basic Sciences, Vol, 5 (11): 1394-1398

[16]. ShahzadFakhar et al, (2013), "Impact of Organizational Culture on Employees Job Performance”,Journal of Business Studies Quarterly, Vol. 5, No.2, PP (56-65).

[17]. Syauta jack henry, et al (2012), “The Influence of Organizational Culture, Organizational Commitment to Job Satisfaction and Employee Performance",International Journal of Business and Management Invention. Volume 1, Issue1. PP (69-76).

[18]. Uddin Mohammad Jasimet al, (2013), "Impact of Organizational Culture on Employee Performance and Productivity" International Journal of Business and Management; Vol. 8, No. 2, PP (63-77).

[19]. XiaojuanZhaug," How Organizational Culture Impact its Performance and Competitiveness". Hubei University of Technology, P.R.China, PP (390-394). Searching engine (Google: 9th Dec. /2014). 